\title{
Community-Based Social Services for Livelihood Recovery after Disaster: Evidence from Post Earthquakes, Lombok, Indonesia
}

\author{
Moh. Taqiuddin* \\ Faculty of Animal Science \\ University of Mataram \\ Mataram, Indonesia \\ m.taqiudin@unram.ac.id
}

\author{
R Rifai \\ Indonesian National Board for Disaster \\ Management \\ Jakarta, Indonesia
}

\author{
Mala Mardialina \\ Department of International Relations \\ University of Mataram \\ Mataram, Indonesia
}

\author{
I Nyoman Nugraha Ardana Putra \\ Faculty of Economics and Business \\ University of Mataram \\ Mataram, Indonesia
}

Maya Atri Komalasari

Department of Sociology

University of Mataram

Mataram, Indonesia

\author{
Ahmad Mubarak Munir \\ Department of International Relations \\ University of Mataram \\ Mataram, Indonesia \\ Yolanda Trisula Sidarta Yohanes \\ Department of Communication \\ University of Mataram \\ Mataram, Indonesia
}

\begin{abstract}
Theoretically and empirically, Indonesia is a country with a high risk of natural disasters. The World Risk Report (2018) noted that Indonesia's risk index is relatively high at 10.36 and ranked $36^{\text {th }}$ out of 172 countries. The risk is driven by the high exposure of most areas of Indonesia to various geophysical and hydro-meteorological hazards combined with several severe vulnerabilities resulting from population growth, unequal economic development, a lack of social and environmental considerations in development processes, and other drivers. Indonesian National Board for Disaster (2019) reported that 2,564 disasters had occurred during 2018 with 3.349 people died, approximately 21,046 people were injured, and 10,2 million people were evacuated or affected. Over three weeks in July-August 2018, a series of massive earthquakes hit the Lombok Island in Eastern Indonesia. Began on 29 July 2018, a 6.4 magnitude earthquake struck North Lombok and East Lombok and just one week later aftershock 7.0 magnitude quake hit the same area again. Consequently, three major earthquakes struck on 9 August (6.2 $\mathrm{M}$ ) and twice on 19 August (6.5 $\mathrm{M}$ and 7.0 M). Indonesian National Board for Disaster (2019) recorded approximately 555 people died and 390,592 were evacuated. The total loss due to these earthquakes was IDR 12.15 Trillion. In this paper we draw on the findings of social impact assessment of partnership between Government and University in implementing of social services for affected- people at recovery stage after the disaster. We argue that community-based social services are an approach that enables community members to play important role in planning and implementing intervention based on their needs. We describe processes to activate locally social capital as an alternative resource for building back better post-disaster more effectively and efficiently.
\end{abstract}

Keywords - community-based, social services, social capital, building back better

\section{INTRODUCTION}

Law of the Republic of Indonesia No. 24/2017 on Disaster Management has defined disaster as event or series of events that threaten and disrupt people's lives and their livelihoods caused by, both natural and/or non-natural factors as well as human factors resulting in human fatalities, environmental damage, property losses, and psychological impacts. BNPB (Indonesian National Board for Disaster) [1] has recorded that disaster events was increased significantly in the last three years. Djalante and Garschagen [2] also analysed the increasing trend of natural disasters, especially floods and earthquakes in Indonesia during 1900-2015. In 2016, BNPB published 1,967 disaster event which had exposed all regions of Indonesia. It was increased to 2,341 times in 2017 with identification of losses as damaged of 47,442 houses, 1272 educational facilities, 113 health facilities, and 698 worship facilities. Meanwhile, the number of disasters decreased in 2018 to 1,999 times but has caused huge losses, as follows: 3,548 people died and disappeared; 13,112 people were injured; 3.06 million people were displaced and affected by the disaster; as well as damages included: 339,969 houses (heavily damaged); 7,810 houses (moderate damage); 20,608 houses (minor damage); and thousands of public facilities. During 2018, hydro-meteorological disasters were dominant. Earthquakes and tsunamis are indeed rare. However, if these two disasters occur, they often cause heavy casualties and economic losses.

During July-August 2018, Lombok Island was shaken by a series of strong earthquakes. Started on July 29, 2018, at 06:47 am, an earthquake with 6.4 magnitudes struck the district of North Lombok, the district of East Lombok and the City of Mataram, West Nusa Tenggara (NTB). Furthermore, on August 5, 2018 at 7:46 pm aftershocks of 7.0 SR occurred again with the epicentre at depth of $15 \mathrm{~km}$. Successively, the next series of major earthquakes were August 9 at $1: 25 \mathrm{pm}(6.2 \mathrm{SR})$ as well as two shocks on August 19 at $12: 10 \mathrm{pm}(6.5 \mathrm{SR})$ and 10:56 pm (7.0 SR). 
BMKG (Meteorology, Climatology and Geophysics Board) has recorded a series of earthquake shocked up to thousands of times each: 5 shocks classified as large with a strength of 6.2-7 SR, 50 medium shocks with magnitude 4-5 SR and thousands of small earthquakes.

Based on geographical location data of the earthquake's distribution, the [3] explained that the series of Lombok earthquakes was caused by Flores faults or more popularly referred to as the Flores Back Arc Thrust which stretches along the seabed of Bali-Flores, westward parallel with the island arch. This fault is known very active due to it was classified as a 'backstabbing' from the operation of the IndoAustralian Plate subduction system which dips beneath the Eurasian Plate. The earthquake shocks for approximately three weeks have resulted in casualties, damage to infrastructure, and refugees to safe locations. [1] recorded 555 people died, 390,592 people were displaced and around 167,961 houses were damaged. Number of infrastructure facilities also had been damaged such as: irrigation canals, office buildings, school buildings, health centers and others. The total loss due to the Lombok earthquake reached Rp 12.15 Trillion.

After the earthquake (aftershock), on July 25, the Provincial Government of NTB issued a decree on emergency response period which purpose to take actions: First, rapid and appropriate assessment of the location, damage, coverage of the disaster site; number of victims; damage to infrastructure, disruption to public service functions and government; and the ability of natural and artificial resources; Second, Rescuing and evacuating affected peoples by: search and rescue victims; emergency aids; and/or evacuate victims; Third, meeting of basic needs, including: clean water and sanitation; food; clothing; health services; psychosocial services; and shelter; Fourth, protection of vulnerable groups (infants, toddlers, and children; pregnant or breastfeeding mothers; people with disabilities; and elderly people); Fifth, immediately recovery of vital infrastructure and facilities which carried out by repair and/or replace damage caused by the disaster.

On August 25, 2018, the Government of Indonesia declared the end of the emergency response period. Furthermore, the President has signed Presidential Instruction (INPRES) No. 5/2018 concerning on the Acceleration of Rehabilitation and Reconstruction of Earthquake Disasters in West Lombok, North Lombok, Central Lombok, East Lombok, Mataram City, and affectedareas in the Province of NTB. By this INPRES, the President instructed the implementation of the acceleration of rehabilitation and reconstruction aftershock to 19 Ministers of Working Cabinet, Commander of the Armed Forces, National Police Chief, Attorney General, Head of BNPB, Head of BPKP, Head of LKPP, Governor of NTB Governor, West Lombok Regent, North Lombok Regent, Central Lombok Regent, East Lombok Regent, and Mayor of Mataram. The post-disaster recovery period will include the process of rehabilitation and reconstruction of public facilities, houses and other vital infrastructure facilities and will end in 2020 .

\section{A. Social Capital and Recovery Post-Disaster}

Post-earthquake recovery is an important phase in restoring the living and livelihood conditions of people after the disaster [4], [5] and is considered as the most complex management function [6]. These views are based on the fact that recovery phase involves the greatest number and variety of stakeholders as well as also provides the greatest effect on the long-term success of the community's socioeconomic recovery [7]. Therefore, Mannakkara [8] emphasizes the need to implement principles of 'building back better' in the recovery process. According to GFDRR [9], Building Back Better (BBB) is a post-disaster recovery approach to reduce disaster's vulnerability in the future and build community resilience to overcome physical, social, environmental and economic shocks.

Previously studies in the case of post-disaster recovery showed that social aspects in the form of social capitals are 'internally force' for communities which play an important role in determining their success to recover [5], [10]-[18]. For example, in Hurricane Katrina, 2005 [19], social relations among individuals in neighboring relationships and other community ties had helped the recovery process more efficiently and reduced economic costs [11], [12], [13]. Likewise, with case of the Aceh Tsunami 2004 recovery, social capital (cooperation, mutual trust, networks, and uleebalang as local institution) have been practiced as an efficient alternative resource in providing and managing of public goods and/or services [15], [16]. Therefore, the social capitals had been recognized as important and useful concepts in hazard and disaster discussions [20].

From the results of these studies as the description above, we argued that social capital have positively impact on efforts for recovering the post-disaster people's livelihood conditions to a 'normal' situation. Collaboration among individuals/people based on mutual trust and bounded by mutual agreement through local institutions are believed to facilitate the supply of needed goods as well as the rebuilding of housing, basic service infrastructure and local economic infrastructure. The model of utilizing social capital as an alternative power or resource for communities to quickly recover from disaster's impacts needs to be developed in the framework of accelerating the recovery of people's livelihoods post-Lombok earthquake.

\section{B. Social Services for Livelihood Recovery After Disaster}

In-Law Number 24 of 2007 articles, 57 and 58 are regulated that the socio-economic and cultural recovery are one of the rehabilitation activities in a post-disaster management context. Article 8 of National Disaster Management Agency Regulation No. 6 of 2017 stated that post-disaster rehabilitation in disaster-affected areas are carried out by recovering and improving of the socioeconomic and culture conditions. A strategy in social recovery context is community-based social services which prioritize the participation of community members in every step of the planned intervention 
In practice, [21] analyzed that social services have largely excluded from preparedness and emergency management efforts. Meanwhile, social services according to an analysis of IOM [22] allow the act to advocates and provides underserved populations, enabling people to access critical goods and services, as well as can help mitigate the impacts of disasters on vulnerable populations. We viewed that social services can activate social capital as an alternative resource to build back better more effectively and efficiently based on local potential. We also believed that social services will provide a 'pathway' to foster the community's sense of belonging to the recovery process as guarantees for program and intervention sustainability towards a 'resilience' in the future.

For resilience, we adopted UN-ISDR's concept as follows: "...the ability of a system, community or society exposed to hazards to resist, absorb, accommodate to and recover from the effects of a hazard in a timely and efficient manner..." [23]. Resilience is a popular concept that providing an integrative 'boundary' in tackling a range of shocks and stresses, including disaster [24]. Unfortunately, this perspective according to Tanner [25] often based on the ability of systems to bounce back to normality, drawing on engineering concepts. This view has been challenged by studies on linked socio-ecological systems which emphasize nonlinear change, uncertainty, interrelationships, and dynamism of multiple cross-scales [26]. We integrated resilience thinking and livelihood approaches to link aspects of human agency, social relation, asset ownership, and transformation as important components of a community or society's ability to adapt, cope with, and recover after the disaster [25]. We used livelihood's concept from Chambers and Conway (1992, p) who had formulated a working definition "a livelihood comprises the capabilities, assets (stores, resources, claims, and access) and activities required for a means of living...". Furthermore, Chambers and Conway [27] elaborated that sustainable livelihood including cope with and recover from stress and shocks due to disaster is one of them as well as maintain or enhance its capabilities and assets.

The Directorate for Socio-Economic Recovery and Improvement BNPB had been carried out social services to restore conditions of people whose affected by disasters in the West Nusa Tenggara region which includes North Lombok Regency, Central Lombok Regency, West Lombok Regency, and East Lombok Regency. This program was conducted by the Central Government collaboration with the University of Mataram (UNRAM) as an effort to overcome social problems which had caused by earthquake which includes sub-sectors: social, psychosocial, arts-cultural, education, health, religious, and historic buildings or heritage. Social services in post-disaster areas based on the needs of affected communities. It was realized to reduce the disaster risk index in high-risk economic growth centers including post-disaster areas as referred to one of the seven development agenda focuses on Presidential Regulation No. 2 of 2015 concern on RPJMN 2015-2019 (National Medium Term Development Plan).
Social services were implemented for 7 (seven) months effectively on 12 targeted groups in 8 (eight) villages and 4 (four) districts. Various consequences of social assistance services at a certain scale and level might arise for social life on targeted groups. In other terms, the post-disaster social recovery intervention activities have social impacts including all social and cultural implications on the existence of them as a result of an action that has been taken. These consequences can lead to changes in norms, values, perspectives, and so on. Referring to this explanation, the consequences of the activities of the social service are both intentional and unintentional as well as positive and negative needs to be studied and analyzed to ensure that the results of interventions that have been implemented can be sustainable in the future.

\section{METHODS}

\section{A. Description of Community-based Social Services}

Social community services of post-disaster in the Lombok Earthquake area is focused on several social subsectors, namely: religion, education, health, socio-culture, social institutions, cultural arts, cultural heritage, youth and psychosocial. The beneficiaries are 12 (twelve) groups in 8 (eight) villages-4 (four) districts, respectively: West Lombok, North Lombok, Central Lombok and East Lombok. The four districts were selected purposively with considerations that these areas: a) categorized as high priority disaster risk as Disaster Risk Index 2015-2019; b) affected by the Lombok earthquake in July-August 2018; c) had formulated and established Post-Disaster Rehabilitation and Reconstruction Action Plan.

The targeted villages as site social services had been determined by the following methods: a) desk study to analyse secondary data that has been collected by other institutions (government, NGOs, and universities) which have been involved in emergency response. These data and information as basis for preparing the criteria of prospective village locations to be consulted with the Provincial and District Governments; b) Focus Group Discussion (FGD) to select and determine candidate site locations in each district. Participants in this activity were representatives of relatedRegional Apparatus Organizations (RAO) both provincial and district levels, respectively: Regional Development Planning Agency, Regional Disaster Management Agency, Social Services Office, etc; c) Rapid Assessment in the proposed-site locations in each district used several methods to gather data and information: secondary data analysis (village monographs, earthquake damage data), direct observations of earthquake impacts focus on social subsectors, in-depth interviews with key informants (head of village, religious leaders, community leaders, youth leaders, and community members); d) Focus Group Discussion with representatives of disaster response-related RAO in each district to determine villages as targeted-location. The following are the targeted-villages as social service site in each district, respectively: District of West Lombok (Saribaye, Sesela); District of Central Lombok (Aik Berik, Teratak); District of East Lombok (Tete Batu, Sembalun 
Lawang); and District of North Lombok (Menggala, Karang Bajo).

Furthermore, the experts of social services were conducted social mapping to analyze 'social setting' (situation and conditions) before and after the earthquake disaster regarding the social-related livelihood aspects, including religion, health, education, heritage, and social institutions. Comparison of conditions "before" and "after" the earthquake has resulted in "gap/problem" in a couple of elements of social sub-sector livelihoods. The determination of social sub-sectors to be serviced in each village used a 'ranking matrix' based on the results of social mapping. The main scoring criteria is "post-disaster change" which had been occurred in elements of each sub-sector. The determination of these criteria are also taken into account the views of Village Governments and Key Figures during social mapping. They viewed that the 'activeness' of social institutions needs to be considered as an 'entry point' for trauma healing (psychic), revives spirit to recover and build awareness or disaster preparedness. The following is a matrix of focussed-social services in each site location:

TABLE I. MATRIX OF FOCUSSED-SOCIAL SERVICES IN EACH SITE LOCATION

\begin{tabular}{|c|c|c|c|}
\hline District & No & $\begin{array}{l}\text { Name of } \\
\text { Village }\end{array}$ & $\begin{array}{c}\text { Sub-sector as focus of } \\
\text { social services }\end{array}$ \\
\hline \multirow{2}{*}{$\begin{array}{l}\text { West } \\
\text { Lombok }\end{array}$} & 1. & Saribaye & Cultural Heritage \\
\hline & 2. & Sesela & Religion \\
\hline \multirow{2}{*}{$\begin{array}{l}\text { Central } \\
\text { Lombok }\end{array}$} & 3. & Aik Berik & Cultural Heritage \\
\hline & 4. & Teratak & Religion \\
\hline \multirow{4}{*}{$\begin{array}{l}\text { East } \\
\text { Lombok }\end{array}$} & \multirow{2}{*}{5.} & \multirow{2}{*}{ Tete Batu } & Cultural Heritage \\
\hline & & & Education \\
\hline & \multirow{2}{*}{6.} & \multirow{2}{*}{$\begin{array}{l}\text { Sembalun } \\
\text { Lawang }\end{array}$} & Health \\
\hline & & & Youth (Social Institution) \\
\hline \multirow{4}{*}{$\begin{array}{l}\text { North } \\
\text { Lombok }\end{array}$} & \multirow{2}{*}{7.} & \multirow{2}{*}{ Karang Bajo } & Religion \\
\hline & & & Cultural Heritage \\
\hline & \multirow{2}{*}{8.} & \multirow{2}{*}{ Menggala } & Health \\
\hline & & & Religion \\
\hline
\end{tabular}

Some of the social services strategies which have been implemented are: a) Need Assessment by a discussion with beneficiaries to select, determine, and prioritize social services' need post-disaster based on social mapping ('gap analysis'); b) Involment of District Government to ensure local government support in recovering and enhancing social activities post-disaster as a strategy for sustainability. They are expected to integrate their programs as stated in Activity Plan and Budget (APB) with community needs; c) capacity building of targeted-groups through activities: training, cross visit, field discussion; d) Exit Strategy Planning through focus group discussion by involving the District Disaster Management Agencies, response-related RAOs, Village Governments, and Community Groups. The aim is to get real support from stakeholders for the next stage after social services activities end.

\section{B. Social Impact Assessment}

Social impact analysis was conducted by rapid assessment with gathering data and/or information both quantitative and qualitative with the main question is "what changes have occurred in social life as outcomes of postdisaster social services?". There are 5 (five) aspects as focus of the social impact analysis on social services activities in post-disaster areas: a) social identity (age, gender, occupation, education, social position, and social welfare category); b) social cohesion (daily relations of the targetedcommunity by exploring of the closeness of social relations between people); c) social learning (continuity of sharing knowledge and experiences processes among others as outcomes of services-related activities); d) social capital (Initiation of networks/linkages with other groups and outsiders; changes in values and norms; the existence of social institutions); e) social participation (active involvement of targeted-groups in social activities especially related to the post-disaster recovery). This social impact analysis is ex-post study because was conducted in early November 2019 when social services had been completed.

\section{RESUlT AND DISCUSSION}

\section{A. Overview of Beneficiries}

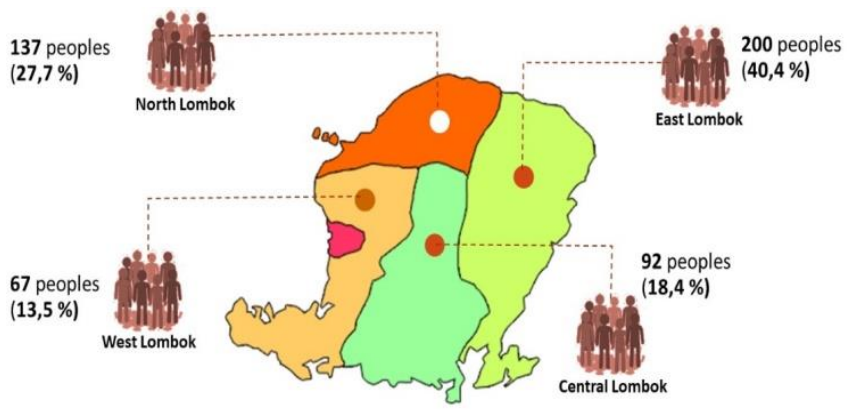

Fig. 1. Distribution of benefeciries by district

The total number of direct beneficiaries of the postdisaster social services activities of BNPB-UNRAM were 495 people with the distribution by the district as shown in Fig. 1. The highest number are beneficiaries in the District of East Lombok who are 200 people $(40.4 \%)$ with a range is 25-90 individuals. Meanwhile, the smallest number are beneficiaries in District of West Lombok, with group members ranging from 20 to 45 individuals. The sub-sector of religion has the largest number of beneficiaries, namely 137 people (34.7\%) which were spread across 3 (three) districts except for East Lombok, with members ranging from 45-65 people. Furthermore, the sub-sector of health has 91 beneficiaries $(27.5 \%)$ in 2 (two) districts i.e: East Lombok and North Lombok. Meanwhile, the sub-sector of arts has around 67 people $(25.1 \%)$ although they are distributed in all districts. Meanwhile, the sub-sector of education and youth are only existing in the District of East Lombok.

The number of women beneficiaries (261 people; 53\%) was slightly higher than that of men (234 people; 47\%). It means that BNPB-UNRAM social services had provided space for everyone, both men and women to be actively 
involved in post-disaster rehabilitation and reconstruction activities. In several studies on disaster-related social aspects [28], [29] explained that women are vulnerable social groups from disaster's impacts. Thus, post-disaster social services were provided women to increase their capacity as an effort to accelerate the recovery of their living conditions toward a return to normal soon.

By age, the largest proportion of beneficiaries are the adult group (26-45 years), namely $50.3 \%$. It can be explained that mostly of the direct beneficiaries are adult individuals (men and women) who have an important role in ensuring the sustainability of their household livelihoods. The involvement of these individuals in social services activities had enabled them to acquire knowledge and skills on accelerating post-disaster recovery. Furthermore, these capacities are expected to be disseminated to the family members and also local community level to ensure that rehabilitation and reconstruction of post-disaster social conditions can proceed as expected.

Beneficiaries of social services have quite a variety of main income sources as the socio-economic conditions of rural communities in general. There are 2 (two) occupations of the targeted services with a large proportion compared to others, namely: farmers (36.8\%) and unemployment $(26.9 \%)$. In this case, unemployment includes housewives and students or they do not have a job as a source of income whether for themselves or their families. In general, beneficiaries have the livelihood base from the processing of natural resources and tend to subsistence like farming. Subsistence patterns of living usually only focus on selfsufficiency and not 'business-oriented. Family savings are generally not in cash but rather in other assets such as livestock, granary, and land.

From the level of education, members of the targeted group can be categorized relatively high because $30.9 \%$ (the highest proportion) among them had completed senior high school. However, the proportion of them with an elementary school and "attending school" are also classified quite high, respectively $22.8 \%$ and $10.3 \%$. The level of education can affect individ preparedness in dealing with disasters. Communities with higher levels of education are more prepared to face disasters than those with low levels of education. Individuals who graduated from college have higher level of preparedness compared with those who are senior high school graduated, junior high school graduates, or elementary school graduates, especially uneducated individuals [30].

In various sociological studies on social structures, it was founded the phenomenon that every individual has certain positions in social life and their placement is not carried out arbitrarily but follows the values or rules that have been applied socially. In this study, social position was operationalized as the position of an individual in the social structure which also reflects their social role. The majority of social positions of post-disaster social services beneficiaries are 'ordinary people' by $84 \%$ and the rest are 'group figures' (religion, society, youth, and women) around $16 \%$. It means that the social services by BNPB-UNRAM are classified as "right on target" because it reached people down to the lower layer (ordinary people) and was not biased to "figures" or "elites". In some government project implementation cases, the targets of them are often 'elite biased' because the beneficiaries are dominated by middle to upper class in society. The determination of "who are the beneficiaries" is sometimes carried out by the village elites or figures.

The welfare level of beneficiaries had been divided into 3 (three) categories, respectively: rich, medium, and poor. In practices, the indicators of these categories were followed the BPS's standards (Central Bureau of Statistics) or refer to the Integrated Database based on the following characteristics: dwelling conditions, ownership of government cards for poor families, and participation in social safety net program: PKH (Hope Family Program) or poor health insurance. From these indicators, the beneficiaries of post-disaster social services were mostly poor households $(58 \%)$. The rest are rich $(24 \%)$ and medium $(18 \%)$ households. The distribution of beneficiaries indicates that most of them are vulnerable to disaster impacts from an economic and social welfare perspective. In normal situations, they always live-in poverty especially when a disaster occurred, it will have impacts on their livelihoods, the ability to raise their family, and the survival of the whole poor family. Therefore, social service had been provided space for them to increase their capacity, especially knowledge, skills, and networks to accelerate efforts to restore their livelihood conditions after the earthquake.

\section{B. Social Services and Livelihood Recovery After Disaster}

The discussion about deliverable-impacts of social services for livelihood recovery after the Lombok earthquake in this article focuses on social life-related aspects. Usman et al [31] explained that many intangible resources are considered important because they used as 'mainstay' for people to recover and survive. They analysed that these non-tangible resources are often ignored by disaster managers, but prove pivotal in sustaining disaster preparedness, mitigation, and rehabilitation. Furthermore, Usman et al [31] detailed that "... the non-tangible assets which include skills training to improve earning opportunities, raising awareness of vulnerable people's right, building the capacity of self-help community groups, and strengthening the involvement of the poor in the decisionmaking process should be enhanced". Some disaster-related studies had proven that intangible resources in the form of social capital are key drivers of sustainable livelihood recovery post-disaster [32], [33], [34] as findings and analysis of this article.

Social services by providing equipment aid for targetedgroups (arts, religion, early childhood education, integrated service posts in health) had been stimulated their spirit and motivation for returning better to normal conditions. One figure of the target group (religious) expressed:

"... These services had reactivated our group... Slowly, we started to forget the earthquake disaster as 
we met each other more often. Our trauma and hurt have been healed. We are excited to carry out our activities..."

The statements of the informant above indicated that their active interactions with each other in activities facilitated by BNPB-UNRAM have fostered their enthusiasm and motivation to recover quickly from trauma due to the earthquake. The social ties from frequently interaction as basis for the targeted-community to activate other social resources. Kim et al [35] concluded that social interaction is an investment of individuals in developing social resources and becoming basis for strengthening community social capital as well as fostering sense of belonging to one another. In the context of post-disaster recovery, interactions between individuals in community can be stimulate motivation and enthusiasm each other to quickly recover together [35], [36] by shared or exchanged of information and experiences. Thus, post-disaster recovery activities involve learning as disaster risk reduction [37] because it can change people's behaviour, perceptions, and emotions.

The argument that post-disaster social services as learning process refers to definition which was formulated by [38] that social learning is an effort to change in understanding of individuals through social interaction between actors in social networks. In the context of social services post-Lombok earthquake, the UNRAM's Team was disseminate information to increase knowledge and understanding of individuals within the targeted-groups. The information contains strategies or ways for post-disaster recovery by functioning and activating social groups to encourage collective actions. In every meeting, the essence of learning was emerged when each individual shared experiences and knowledge about what has been seen, what has been felt, what has been done during post-disaster situations. In the youth group, social services provided trainings on post-disaster livelihood strategies adjusted to local problems and potentials as results of previously situational analysis. The kinds of these training are processing organic waste into items of economic value and how to become tour guides for mountain climbing.

\section{CONCLUSION}

Recovery of post-disaster community livelihood must pay attention to socio-cultural aspects, especially the supply of social capital which was developed and practiced in midst their everyday life. The strategy of post-disaster social condition recovery is community-based social services by prioritizing participation of community members as the main actor who plays an important role in every plannedintervention. The main principles of community-based social services are: based on the affected-community needs in order to decrease the disaster risk index; activation of local community social capital as an alternative resource to building back better more effectively and efficiently based on local potential; foster a sense of community ownership to ensure the sustainability aspects.

\section{ACKNOWLEDGMENT}

All of post-disaster social services activities including this research has been supported and funded by The Indonesian National Board for Disaster Budget 2019. We thank to: Head of Indonesian National Board for Disaster; Deputy and staff of Rehabilitation and Reconstruction Indonesian National Board for Disaster, Rector of University of Mataram; Head of Research Institute University of Mataram.

\section{REFERENCES}

[1] BNPB, Indo. "TANGGAP TANGKAS TANGGUH Menghadapi Bencana." (2019).

[2] Djalante, Riyanti, et al. Disaster Risk Reduction in Indonesia. Fujisawa, Japan: Springer. https://doi. org/10.1007/978-3-319-544663, 2017.

[3] Grigoli, Francesco, et al. "The November $2017 \mathrm{Mw} 5.5$ Pohang earthquake: A possible case of induced seismicity in South Korea." Science 360.6392 (2018): 1003-1006.

[4] Olshansky, Robert, and Stephanie Chang. "Planning for disaster recovery: Emerging research needs and challenges." Progress in planning 72.4 (2009): 200-209.

[5] Nations, U. "UNISDR terminology on disaster risk reduction." United Nations Office for Disaster Risk Reduction, Report (2009).

[6] Imperiale, Angelo J., and Frank Vanclay. "Command-and-control, emergency powers, and the failure to observe United Nations disaster management principles following the 2009 L'Aquila earthquake." International journal of disaster risk reduction 36 (2019): 101099.

[7] Mannakkara, Sandeeka, Suzanne Wilkinson, and Tinu Rose Francis. "Build Back Better" principles for reconstruction." Encyclopedia of Earthquake Engineering; Beer, M., Kougioumtzoglou, IA, Patelli, E., $A u, S .-K ., E d s$ (2014): 1-12.

[8] Colombia, Banco Mundial. "Global Facility for Disaster Reduction and Recovery (2012)." Análisis de la gestión del riesgo de desastres en Colombia: un aporte a la construcción de políticas públicas.

[9] Muktiali, Mohammad. "Partisipasi Masyarakat Dalam Kegiatan Perencanaan Rekonstruksi Dan Rehabilitasi Pasca Bencana (Studi Kasus Di Kabupaten Nias Selatan, Sumatera Utara)."

[10] Chamlee-Wright, Emily, and Virgil Henry Storr. "Club goods and post-disaster community return." Rationality and Society 21.4 (2009): 429-458.

[11] Chamlee-Wright, Emily, and Virgil Henry Storr. "“There's no place like new orleans": Sense of place and community recovery in the ninth ward after hurricane katrina." Journal of Urban Affairs 31.5 (2009): 615-634.

[12] Chamlee-Wright, Emily, and Virgil Henry Storr. "“There's no place like new orleans": Sense of place and community recovery in the ninth ward after hurricane katrina." Journal of Urban Affairs 31.5 (2009): 615-634

[13] Aldrich, Daniel P. "Social capital in post disaster recovery: towards a resilient and compassionate East Asian community." Economic and welfare impacts of disasters in East Asia and policy responses (2012): 157-178.

[14] McCarthy, John F. "Using community led development approaches to address vulnerability after disaster: Caught in a sad romance." Global environmental change 27 (2014): 144-155.

[15] Muharja, Fajri, and Teguh Dartanto. "Habis bencana terbitlah terang: sepuluh tahun pasca tsunami Aceh 2014 (Analisis proses pemulihan dengan data outer space)." Prosiding Seminar Nasional: Perkembangan teori ekonomi dan metode pembelajaran ilmu ekonomi 2013-2016. 2017.

[16] Alipour, Fardin, et al. "Social issues and post-disaster recovery: A qualitative study in an Iranian context." International Social Work 58.5 (2015): 689-703.

[17] Marin, Andres, et al. "Social capital in post-disaster recovery trajectories: Insights from a longitudinal study of tsunami-impacted small-scale fisher organizations in Chile." Global Environmental Change 35 (2015): 450-462 
[18] Brunkard, Joan, Gonza Namulanda, and Raoult Ratard. "Hurricane katrina deaths, louisiana, 2005." Disaster medicine and public health preparedness 2.4 (2008): 215-223.

[19] Mayunga, Joseph S. "Understanding and applying the concept of community disaster resilience: a capital-based approach." Summer academy for social vulnerability and resilience building 1.1 (2007): 1-16.

[20] White, Hayden. Metahistory: The historical imagination in nineteenth-century Europe. JHU Press, 2014.

[21] Institute of Medicine, et al. Healthy, Resilient, and Sustainable Communities After Disasters: Strategies, Opportunities, and Planning for Recovery. National Academies Press, 2015.

[22] Nations, U. "UNISDR terminology on disaster risk reduction." United Nations Office for Disaster Risk Reduction, Report (2009).

[23] Brand, Fridolin Simon, and Kurt Jax. "Focusing the meaning (s) of resilience: resilience as a descriptive concept and a boundary object." Ecology and society 12.1 (2007).

[24] Tanner, Thomas, et al. "Livelihood resilience in the face of climate change." Nature Climate Change 5.1 (2015): 23-26.

[25] Folke, Carl. "Resilience: The emergence of a perspective for socialecological systems analyses." Global environmental change 16.3 (2006): 253-267.

[26] Chambers, Robert, and Gordon Conway. Sustainable rural livelihoods: practical concepts for the 21st century. Institute of Development Studies (UK), 1992.

[27] Blake, William. Songs of Innocence and of Experience. Vol. 5. Princeton University Press, 1994.

[28] Ghofur, Abdul, Bambang Irawanto, And Lucia Ratnasari. Pelabelan Super Edge Graceful Pada Path Dan Fan Graph. Diss. Faculty Of Mathematics And Natural Science, 2012.

[29] Fitriningtiyas, Kurnia. Hubungan Tingkat Pendidikan Formal Dengan Kesiapsiagaan Dalam Menghadapi Bencana Gempa Bumi Masyarakat
Desa Jabung Kecamatan Gantiwarno Kabupaten Klaten. Diss. Universitas Muhammadiyah Surakarta, 2014.

[30] Usman, Raheem A., et al. "Disaster risk management and social impact assessment: Understanding preparedness, response and recovery in community projects." Environmental change and sustainability (2013): 259-274.

[31] Aldrich, Daniel P. "Social capital in post disaster recovery: towards a resilient and compassionate East Asian community." Economic and welfare impacts of disasters in East Asia and policy responses (2012): 157-178.

[32] Aldrich, Daniel P., and Michelle A. Meyer. "Social capital and community resilience." American behavioral scientist 59.2 (2015): 254-269.

[33] Monteil, Charlotte, Peter Simmons, and Anna Hicks. "Post-disaster recovery and sociocultural change: Rethinking social capital development for the new social fabric." International Journal of Disaster Risk Reduction 42 (2020): 101356.

[34] Kim, Christopher, et al. "The effect of social capital on community co-production: Towards community-oriented development in postdisaster recovery." Procedia engineering 180 (2017): 901-911.

[35] Anquetil, Virginie. "Neighbourhood social cohesion through the collective use of green spaces: A case study of EVA-Lanxmeer neighbourhood, Culemborg, the Netherlands." Wageningen UR: Alterra (2009).

[36] Kitagawa, Kaori. "Disaster risk reduction activities as learning." Natural Hazards 105.3 (2021): 3099-3118.

[37] Reed, Mark S., et al. "What is social learning?." Ecology and society 15.4 (2010) 